\title{
The Effectiveness of Capital Controls: The Case of Slovenia
}

\author{
Claudia M. Buch \\ The Kiel Institute of World Economics \\ Elke Hanschel \\ Swiss Federal Finance Adminstration
}

\begin{abstract}
Similar to Chile in the 1990s, Slovenia has introduced an unremunerated reserve requirement (URR) on financial credits in 1995. We find that the URR has not been effective in reducing overall inflows offoreign capital. Hence, the gain in monetary autonomy has been limited. While the overall structure of capital inflows has not differed decidedly from that of other transition economies, Slovenia has raised less short-term bank credit from abroad. Moreover, there are indications that the volatility of exchange rates has declined after the imposition of the URR while the volatility of capital flows has increased
\end{abstract}

- JEL classification: F21, F32, F36

- Key Words: Slovenia, Capital Controls

\section{Motivation}

Recent financial crises in south-east Asia, Russia, or Brazil have heightened concerns about a speedy liberalization of capital flows. ${ }^{1}$ The emerging market

*Corresponding Address: The Kiel Institute of World Economics Düsternbrooker Weg 12024105 Kiel., Germany Phone: +49-431-8814-332. Fax: +49-431-85853. EMail: cbuch@ifw.uni-kiel.de. Elke Henschel, Swiss Federal Finance Administration IMF and International Finance. Phone: +41-31-322 61 66. Fax: +41-31-323 08 33. Email: elke.hanschel @efv.admin.ch

**The authors would like to thank Jörg Döpke, Jöt Kleinert, Harmen Lehment, Peter Zajc as well as the participants of the ASP termpaper conference of May 1999 for providing valuable information and helpful comments on an earlier draft. All remaining errors and inaccuracies are solely in our own responsibility.

${ }^{1}$ See, for instance, Eichengreen et al. (1998) and Fischer et al. (1998). 
economies of central and eastern Europe are a group of countries for which policy lessons seem particularly urgent. Not only have these economies opened up for foreign capital fairly recently and have attracted quite substantial amounts of foreign finance, successfully completing the process of $\mathrm{EU}$ accession also requires the abolition of remaining restrictions to the free flow of capital.

Among the most advanced reform states, Slovenia is the country which has taken the most restrictive stance vis-à-vis foreign capital. Slovenia has restricted capital inflows in 1995 and has adjusted the foreign exchange law several times since then. Policy makers have followed the example of Chile by imposing an unremunerated reserve requirement (URR) on financial credits in order to deal with increasing capital inflows. Chile introduced the measure already in 1991. However, it lowered the reserve requirement drastically in 1998, and also Slovenia set the rate to zero in January 1999. The policy stance chosen by Slovenia is in contrast to the relatively speedy progress towards capital account convertibility that other transition economies and accession states have made.

The aim of this paper is to assess Slovenia's experience with the URR. Section II describes the system of capital account restrictions and compares it to the strategies of other EU accession states. Section III briefly reviews the theoretical and empirical literature on capital controls. Section IV presents stylized facts of Slovenia's macroeconomic development in the past. Evidence from other advanced reform states (Czech Republic, Estonia, Hungary, and Poland) which are, as Slovenia, included in the first round of EU candidates, is presented as a benchmark. Section V presents an analysis of the effectiveness of Slovenia's capital controls.

To our knowledge, this is the first study to deal with the Slovene case. Overall, we find that the Slovene URR has not been effective in reducing total inflows of foreign capital. Hence, the gain in monetary autonomy has been limited. While the overall structure of capital inflows has not differed decidedly from that of other transition economies, Slovenia has raised relatively less short-term bank credits from abroad. Moreover, there are indications that the volatility of exchange rates has declined after the imposition of controls while the volatility of capital flows has increased. Hence, the controls have been unsuccessful in shielding the Slovene economy from recent increases in the volatility of financial markets. By and large, these results confirm the findings of earlier studies which found limited and at best short-lived effects of capital controls. 


\section{Institutional Background}

Since the demise of the communist regime in the late 1980s, under which the transition economies of central and eastern Europe were virtually closed off from the private international capital market, progress in capital account liberalization has advanced quite far in the countries under review. Generally, a gradual reform sequence has been chosen: current account convertibility was established relatively soon but capital flows have remained more tightly regulated. ${ }^{2}$

\section{A. External Convertibility}

Slovenia had, after the declaration of independence in June 1991, a gross domestic product (GDP) per capita that exceeded that of other central and eastern European transition economies, and the country was relatively open with regard to foreign trade. Slovenia conducted about 30 percent of Yugoslavias total exports in 1990 and accounted for nearly 25 percent of total imports. This roughly corresponded to Slovenias share in former Yugoslovias GDP (as of 1993). In 1990, the main trading partners were countries of the EU; 40 percent of Slovene exports went to Germany and Italy (OECD 1997).

International capital flows were not very high in the first year after independence, one reason being the unstable political situation in neighboring countries. In 1993, capital inflows started to rise, increasing from 229 to 810 million US-dollar annually or the equivalent of 2.3 percent of GDP up until 1995. ${ }^{3}$ The formerly positive current account turned into a small deficit in 1995. Large interventions in the foreign exchange market were carried out by the central bank. And, being a small open economy, Slovenia became particularly vulnerable to swings in capital flows. Therefore, in February 1995, the Bank of Slovenia (BOS) imposed controls on capital inflows that contained a registration requirement for foreign direct investments (FDI), special "custody accounts" at licensed banks for portfolio investments, and an URR for financial credits. The purchase of land or real estate is not allowed for foreigners.

The URR for financial credits aims particularly at discouraging short-term capital inflows. Starting in February 1995, 40 percent of each financial credit from abroad had to be put in a non-interest bearing account at the BOS for the period

\footnotetext{
${ }^{2}$ See Backé (1996) and Buch et al. (1999) for surveys of the current and capital account restrictions in the Visegrad countries and in Slovenia.

${ }^{3}$ See Section 4, Table 1 for macroeconomic developments in the accession states.
} 
of two years if the financial credit had a maturity of up to seven years. For longer maturities, the deposit requirement was only 10 percent. This regime is similar to the one Chile has introduced in $1991 .^{4}$ Although being designed in the spirit of Tobin's proposal to throw some sand in the wheels of excessively efficient international money markets (Tobin 1978), URRs of the Slovene (or Chilean) type do not qualify as pure Tobin taxes. This is because they are not levied on all capital account items and because they are not imposed multilaterally. But clearly the Slovene capital controls "punish" short-term capital flows more severely than long-term flows, one takes the annualized foregone interest into account. In January 1999, the BOS set the URR to zero, signaling that more foreign credits would be desired. ${ }^{5}$ As the system has not been abandoned entirely, the BOS in principle has the option to raise the reserve requirement on short notice.

Slovenia's integration strategy differs from the policies which other EU accession states have pursued. Although there has been a tendency to retain restrictions in particular on short-term capital flows as well as the option to resort to emergency measures in times of severe balance of payments problems, the other accession states have been more liberal with regard to capital (in)flows. The most liberal regime has been pursued by Estonia where full capital account convertibility was introduced in May 1994. Common features of the Czech, Hungarian, and the Polish foreign exchange laws are a more liberal regime on FDI than on other capital account transactions as well as less restrictions on capital inflows than on outflows. FDI has been generally liberalized. Inward portfolio investment in bonds and equity is typically permitted but the placement of domestic securities abroad usually requires a permission. Mid- and long-term financial credits have been liberalized throughout the region; Czech residents can also borrow short-term funds from abroad.

\section{B. Exchange Rate Policies}

Typically, transition economies have chosen the exchange rate as a nominal anchor for their stabilization policies. While Poland (in 1991) and Hungary (in early 1995) have moved to a crawling peg regime, Estonia has followed the most restrictive policy of the countries under study since it has tied its currency to the D-mark (euro) under a currency board regime. The Czech National Bank

\footnotetext{
${ }^{4}$ In June 1991, Chile adopted an URR on foreign credits. Until 1998, when the reserve requirement was drastically lowered, capital controls were gradually extended. See Valdés-Prieto and Soto (1998).

${ }^{5}$ See Bank of Slovenia (1999).
} 
Figure 1. Exchange Rates to the US-Dollar and to the D-Mark (1993-1998).

(a) Nominal (US-dollar)

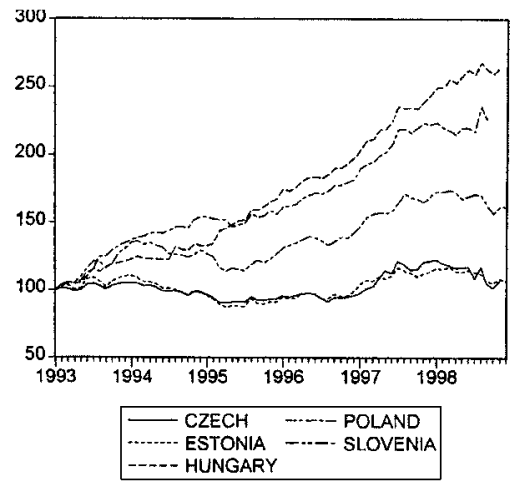

(c) Nominal (D-mark)

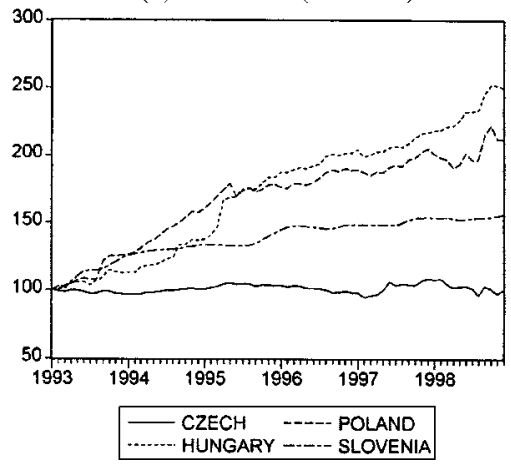

(b) Real (US-dollar)

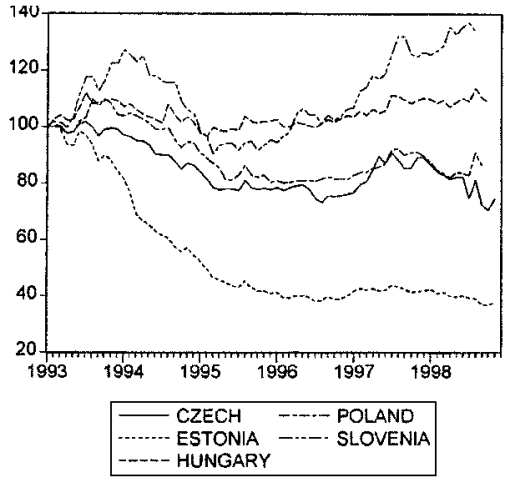

(d) Real (D-mark)

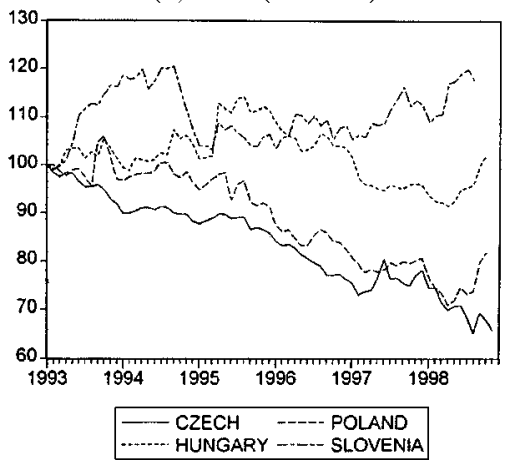

Notes: increase $=$ depreciation. January 1993=100. Real exchange rates are CPI-based. Source: IMF (1999b)

maintained a fixed parity to the D-mark until May 1997 when a speculative attack forced it to abandon the peg. Since then, it has followed a strategy of dirty floating.

Slovenia was the first country of former Yugoslavia that reached monetary independence. It has likewise chosen a strategy of dirty floating with the D-mark (euro) serving as a reference currency, however this was not explicitly announced. Yet, actual exchange rate developments show a much smoother evolution of the tolar-D-mark exchange rate as compared to the tolar-US-dollar rate (Graph 1). Since 1993, the rate of depreciation of the tolar has been below the rates observed for Hungary or Poland but above corresponding values for the Czech Republic or Estonia.

The primary objectives of the BOS are exchange rate and price stability by

${ }^{6}$ From 1991 to 1996 , the monetary target was M1. In 1997, the BOS has switched to an M3-target (Lavrac and Stanovnik 1997: 154). 
intermediate monetary targeting. ${ }^{6}$ The choice of a dirty floating exchange rate system has been based on considerations that Slovenia is strongly export-oriented and that an overvalued fixed exchange rate could harm the reform process. Furthermore, the fact that Slovenia had just after independence almost no foreign exchange reserves may explain the reluctance to announce officially the maintenance of a fixed parity.

By and large, the BOS has been relatively successful in containing real appreciation of the currency. After a period of depreciation in 1993, which was interrupted by a period of an appreciating exchange rate in 1995, the tolar has depreciated in real terms quite continuously after 1995. This holds true both for the D-mark and for the US-dollar exchange rate. The successful prevention of a real appreciation (and even a certain real depreciation) is in contrast to the experiences of other transition economies, and has helped to maintain competitiveness in the export sector.

\section{External Commitments}

In early 1998, accession talks of the European Union with a group of ten applicants, among them the five countries studied here, have started. The envisaged membership of the EU and the concomitant participation in the Single Market is by far the most challenging commitment regarding capital account liberalization faced by the new members. The ground for membership was laid in December 1991 when the Visegrad countries signed Europe Agreements with the EU; Slovenia signed its Europe Agreement in January 1992. While the Agreements already contained provisions with regard to the market entry of foreign banks and the liberalization of capital flows, full membership will eventually go substantially beyond these requirements.

One essential part of the accession strategy is the White Book of May 1995 in which the EU has outlined the prerequisites for accession. Members of the EU must accept the entire acquis communautaire and the regulations of the internal market. This implies, among others, the acceptance of the principles of mutual recognition of banking licenses, of minimum harmonization, and of home country control, which are enshrined in the Second Banking Directive of the EU of 1993. Capital account liberalization follows a gradual strategy. In a first stage, only medium- and long-term capital flows must be liberalized, short-term capital flows follow in the second stage. Restrictions can then be maintained only in exceptional cases and upon approval of the EU Commission. ${ }^{7}$ 
The European Commission is reporting annually on the progress made by each of the five accession countries. For Slovenia, the report of October 1999 includes, among other issues, ${ }^{8}$ the assessment in terms of the Copenhagen criteria: First, the countries must be a functioning market economy and second, they have to be able to withstand competitive pressures and market forces within the EU. Slovenia is being considered to fulfill the first criterion. Macroeconomic stabilization is relatively well established, and the reform process is under way. However, it is also stressed that macroeconomic achievements have been made under conditions of a relatively closed capital flow regime. On the second criterion, Slovenia has improved continuously its ability to meet competitive pressures, although the speed of reform is a point of critique. Improvements are requested in the banking sector, in particular with regard to the privatization of the two largest banks and the improvement of corporate governance and financing of investment through banks.

\section{Previous Evidence on Capital Controls}

After recent experiences of volatile financial markets, weaknesses in the international financial architecture have been discussed increasingly. ${ }^{9}$ The question has been raised whether (temporary) capital controls should be used to stem surges of capital flows. Reserve requirements in the spirit of Tobin's original proposal, which particularly raise the costs of short-term financial flows, have become popular. Chile (1991-1998), Spain (1987-1991), Colombia (since 1993), and Slovenia (1995-1999) are examples of such restrictions. In reviewing the theoretical and empirical literature, our intuition is to show which macroeconomic variables are the target of policy makers and how one can measure, empirically, the influence of capital controls on these macroeconomic variables. The effectiveness of capital controls is subject to controversy, and we argue that capital controls are desirable only if they influence policy targets in the appropriate way,

\footnotetext{
${ }^{7}$ OECD membership additionally requires prospective members to phase out capital controls. Prior to a formal membership, the OECD Code of Liberalization of Capital Movements has to be fulfilled. The Code reaches further than the requirements of EU membership because it includes an "extended liberalization of capital movements" which is de facto a complete liberalization of the capital account. Exemptions are given only to member countries that were member of the OECD before the adoption of the Code. See Quirk and Evans (1995). The Czech Republic, Hungary and Poland are already members of the OECD, Estonia and Slovenia had not yet joined at the time of writing.

${ }^{8}$ For details see European Commission (1999).

${ }^{9}$ See Roubini (1999) as well as Eichengreen (1999).
} 
otherwise there is a risk that the economy moves from a second-best to a third-best equilibrium.

The first-best equilibrium in a world with fully efficient capital markets is free capital mobility. If there exist distortions, e.g. imperfect information, moral hazard problems, lack of credibility, or weak banking systems, temporary capital controls can be welfare improving until the distortions have been removed. In the case of transition economies, ${ }^{10}$ three main motivations for capital controls and can be identified:

First, countries that pursue a fixed exchange rate system aim at gaining some monetary autonomy that allows to drive a (small) wedge between domestic and foreign interest rates. Although a higher domestic interest rate would attract more capital inflows, with the restriction in place, the otherwise resulting appreciation of the exchange rate is dampened. The macroeconomic variables affected are the (real) exchange rate, the interest rate differential, and the volume of net capital inflows. When testing for the effectiveness of capital controls, one has to be aware that controls might be circumvented. Actors on financial markets are very innovative and profit from possible arbitrage opportunities. This argument is supported by the observation that capital controls usually need to be tightened continuously. Therefore, it is also interesting to establish for how long the effects of capital controls last.

Second, prudential motivations may lead to the introduction of capital controls. The aim is to discourage short-term external borrowing, which may be high particularly if commercial banks are protected by a government guarantee of their deposits. In such a scenario, over-borrowing may occur in the sense that commercial banks assume risk in excess of what they would have taken in the absence of deposit protection. Eventually, in the event of a crisis, the government might be forced to take on these obligations, and this may trigger additional adjustment problems. ${ }^{11}$ In the case of Slovenia, this risk seems particularly accute since the government still holds significant stakes in the largest banks of the country and thus provides an implicit deposit guarantee. ${ }^{12}$ In such as situation, URRs are intended to change the structure of capital inflows in favor of longerterm capital, and in particular equity financing. The main rationale for this change in the structure of capital flows is that long-term capital flows are deemed to be

\footnotetext{
${ }^{10}$ This is also true for emerging market economies that are opening up their financial markets. For developing countries there are more motivations identified, e.g. the retention of domestic savings. See Dooley (1996) for details.

${ }^{11}$ See, for instance, Krugman (1998) and McKinnon and Pill (1995) for a theoretical discussion of this effect.
} 
less volatile than short-term flows and that long-term investment are considered to be financed optimally via long-term funds. ${ }^{13}$ At the same time, however, the reduction of short-term capital flows could tend to discriminate small- and midsized domestic borrowers who tend to lack access to alternative sources of funds (Valdés-Prieto and Soto 1998).

Third, transactions taxes can reduce the volatility of nominal (and real) exchange rates which ensues from domestic money supply shocks (Buch et al. 1998). Yet, the implementation of a transactions tax by itself is an exogenous shock which pushes the economy to a new steady state. The new steady state is characterized by a depreciated domestic currency and a higher domestic price level. Moreover, sluggish price adjustment on the commodity market relative to the financial market causes a temporary overshooting of the exchange rate compared to the new long-run equilibrium level. The implementation of a transactions tax on cross-border capital flows thus by itself induces fluctuations of the exchange rate.

As regards the empirical evidence, most work on URRs has been done for Chile. Laurens and Cardoso (1998) review this literature which finds that the URR did not succeed in reducing overall capital inflows, in affecting the level of the real exchange rate, or in giving the monetary authorities sustained leeway with regard to domestic interest rates. Evidence on the impact of the URR on the composition of capital inflows is mixed, while the controls may have served to reduce the volatility of the real exchange rate. Edwards (1998) analyzes the impact of the capital controls on the real exchange rate and on interest rate differentials using vector auto regressions (VAR). He finds the impact of controls to be rather small and short-lived. Furthermore, he shows that the volume of capital inflows has continued to increase after the imposition of the controls.

Laurens and Cardoso (1998) also review the empirical literature on the effectiveness of capital controls in general. In econometric studies, the most frequently used dependent variable is net capital inflows. Some of the model specifications are not very profound, and one finds ad-hoc specifications of capital flows. ${ }^{14}$ Earlier studies mostly use ordinary least square regressions and concentrate on interest rate differentials. For countries that do not have a forward

\footnotetext{
${ }^{12}$ Analyzing the microeconomic structure of the Slovene banking sector and the implications for the risk taking of banks is beyond the scope of the present paper. For an overview of the current situation see EU (1999) or Moore and Zajc (1999).

${ }^{13}$ See Claessens et al. (1995) and Sarno and Taylor (1999) for a discussion of the volatility features of different types of capital flows

${ }^{14}$ On similar grounds, Nadal-de Simone and Sorsa (1999) criticize the evidence on Chile.
} 
exchange rate market, the actual rate of devaluation is typically taken as a proxy for exchange rate expectations. ${ }^{15}$ Johnston and Ryan (1994) include dummies for the intensity of controls on in- and outflows in their regressions explaining net capital flows. The specification of the regression equation is based on combined elements of a portfolio and a balance of payments model. Johnston and Ryan estimate the effects of interventions in the capital markets for a sample of 52 countries in the period from 1985 to 1992. A similar methodology is used by Lee (1996) who includes a dummy for capital controls. In his study, three developing countries (Indonesia, Korea and Thailand) and one industrial country (Spain) are analyzed. Both Johnston/Ryan, and Lee find the effectiveness of capital controls to be of a short duration.

More recent studies typically make use of more sophisticated econometric techniques. The common intuition is to overcome the problem of the possible endogeneity of capital controls. Chile, Slovenia, and other countries reacted to increasing capital inflows by strengthening their controls. ${ }^{16}$ Therefore, Dooley, Mathieson, and Rojas-Suarez (1997) use a two-stage, instrumental variable Kalman-filter estimator. Cardoso and Goldfajn (1998) as well as Edwards (1998) use structural VARs. The results of these papers are similar to earlier findings: the effectiveness of capital controls is limited to a short-period of time, regardless of the variable that is intended to be affected (real exchange rate, interest rate differential, or net capital inflows). The countries analyzed (Brazil, Chile, Colombia, Indonesia, Korea, Spain, or Thailand) have often shortcomings in their data bases and/or the time period of the capital controls being active; therefore, the results have to be interpreted with caution. The same caveat applies to the following analysis of Slovenia. The reliability of the database, in particular for the time prior to the introduction of the URR is poor, and key macroeconomic variables have been very volatile back then. Hence, instead of drawing on a single measure of the effectiveness of the controls, we provide a number of indicators and tests. Moreover, we present data from other transition economies as a control group.

\section{Stylized Facts}

Prima facie, the imposition of capital controls seems not to have affected economic development of Slovenia to a significantly (negative) degree. Table 1

\footnotetext{
${ }^{15}$ See Edwards and Khan (1985), Haque and Montiel (1990), or Cardoso and Laurens (1998).

${ }^{16}$ See Cardoso and Goldfajn (1998) who refer to the reverse causality from capital flows to controls by explicitly modeling a government reaction function
} 
Table 1. Macroeconomic Developments in the Accession States (1992-1998 $)$

\begin{tabular}{|c|c|c|c|c|c|c|c|}
\hline & 1992 & 1993 & 1994 & 1995 & 1996 & 1997 & 1998 \\
\hline & \multicolumn{7}{|c|}{ GDP growth (\% per annum) } \\
\hline Czech Republic & 3.3 & 0.6 & 3.2 & 6.4 & 3.9 & 1 & 2.5 \\
\hline Estonia & 12.4 & 8.5 & 1.8 & 4.3 & 4 & 11.4 & 6.4 \\
\hline Hungary & 3.1 & 0.6 & 2.9 & 1.5 & 1.3 & 4.4 & 5.0 \\
\hline Poland & 2.6 & 3.8 & 5.2 & 7.0 & 6.1 & 6.9 & 5.5 \\
\hline \multirow[t]{2}{*}{ Slovenia } & $\ldots$ & 1.3 & 5.3 & 4.1 & 3.1 & 3.8 & 2.3 \\
\hline & \multicolumn{7}{|c|}{ Consumer price inflation (\% per annum) } \\
\hline Czech Republic & 10.9 & 10.1 & 9.1 & 8.8 & 8.4 & 10.7 & 6.6 \\
\hline Estonia & $\ldots$ & 89.8 & 47.7 & 28.8 & 23.1 & 10.6 & 6.6 \\
\hline Hungary & 22.9 & 22.5 & 18.9 & 28.3 & 23.5 & 18.3 & 14.4 \\
\hline Poland & 45.3 & 36.9 & 33.3 & 26.8 & 20.2 & 15.9 & 11.7 \\
\hline \multirow{2}{*}{ Slovenia } & 31.9 & 19.8 & 12.6 & 9.7 & 9.1 & 8.6 & 7.9 \\
\hline & \multicolumn{7}{|c|}{ Budget deficit (\% of GDP) } \\
\hline Czech Republic & -3.3 & 0.1 & 0.9 & 0.5 & -0.1 & -1 & 0.3 \\
\hline Estonia & 1.2 & -2.1 & 1.4 & 0 & -0.7 & 2.4 & $\ldots$ \\
\hline Hungary & -7.3 & -5.7 & -7.1 & -6.4 & -3.1 & -4.7 & -4.6 \\
\hline Poland & -6 & -2.8 & -2.3 & -2.0 & -2.2 & -1.4 & -2.5 \\
\hline \multirow[t]{2}{*}{ Slovenia } & 0.2 & 0.3 & -0.2 & -0.3 & 0.3 & -1.1 & $\ldots$ \\
\hline & \multicolumn{7}{|c|}{ Current account (\% of GDP) } \\
\hline Czech Republic & $\ldots$ & 1.5 & -1.9 & -2.7 & -7.7 & -6.9 & -8.2 \\
\hline Estonia & 3.6 & 1.4 & -6.8 & -4.4 & -9.4 & -12.4 & -9.7 \\
\hline Hungary & 1.0 & -12.1 & -10.3 & -6.4 & -4.1 & -2.1 & -4.7 \\
\hline Poland & -4.3 & -7.9 & 1.1 & 0.7 & -2.6 & -4.5 & -4.5 \\
\hline \multirow[t]{2}{*}{ Slovenia } & 9.5 & 1.8 & 4.1 & -0.1 & 0.2 & 0.2 & -1.0 \\
\hline & \multicolumn{7}{|c|}{ Import reserve coverage (months) } \\
\hline Czech Republic & $\ldots$ & $\ldots$ & 4.3 & 6.7 & 5.4 & 4.3 & 6.8 \\
\hline Estonia & $\cdots$ & 4.9 & 3.4 & 2.9 & 2.7 & 2.7 & 2.5 \\
\hline Hungary & $\ldots$ & 6.7 & 7.2 & 9.5 & 7 & 4.7 & 4.8 \\
\hline Poland & $\ldots$ & 3 & 3.8 & 0.7 & 6.2 & 6.1 & 7.4 \\
\hline \multirow[t]{2}{*}{ Slovenia } & $\ldots$ & 1.5 & 2.5 & 2.3 & 3 & 4.3 & 4.4 \\
\hline & \multicolumn{7}{|c|}{ Capital and financial account, reserves excluded (\% of GDP) } \\
\hline Czech Republic & $\ldots$ & 7.4 & 8.3 & 16.2 & 7.7 & 2.4 & 4.8 \\
\hline Estonia & 4.6 & 6.6 & 0.7 & 6.8 & 4.9 & 6.4 & 8.9 \\
\hline Hungary & 1.1 & 15.8 & 7.7 & 13.1 & -3.6 & 1.1 & 5.0 \\
\hline Poland & 4.6 & 6.6 & 0.7 & 6.8 & 4.9 & 6.4 & 7.6 \\
\hline \multirow[t]{2}{*}{ Slovenia } & $\ldots$ & -0.8 & 0.8 & 2.3 & 3.0 & 6.9 & -0.0 \\
\hline & \multicolumn{7}{|c|}{ Foreign debt (\% of GDP) } \\
\hline Czech Republic & 27.1 & 29.4 & 26.2 & 33.1 & 38.1 & 44.9 & 39.1 \\
\hline Estonia & 1.4 & 3.9 & 4.8 & 7.1 & 9.3 & 14.9 & 16.0 \\
\hline Hungary & 59.1 & 63.0 & 69.0 & 72.4 & 62.3 & 56.6 & 55.2 \\
\hline Poland & 57.5 & 52.5 & 45.6 & 38.1 & 32.7 & 28.4 & 23.9 \\
\hline Slovenia & $\ldots$ & 15.1 & 15.8 & 16.4 & 21.7 & 25.7 & 24.2 \\
\hline
\end{tabular}

a) Data for 1998 were taken from national sources and are not consistent necessarily with earlier data. GDP and GDP growth rates for 1998 are based on estimates, except for Slovenia. Source: IMF (1999b), Commerzbank (1999), national sources, own calculations. 
compares selected macroeconomic indicators for the transition economies under review. Although growth of Slovene GDP slowed down after 1994, rates were still comparable to those of the Czech Republic or Hungary. In 1998, economic growth of Slovenia reached 2.3 percent, lagging somewhat behind Estonia, Hungary, or Poland while outperforming the Czech Republic, which was still recovering from its financial and economic crisis of 1997.

Slovene consumer price inflation dropped to single digit levels in 1995 and reached 7.9 percent in 1998. Of the accession states only the Czech Republic disinflated more rapidly, taking the in 1997 as an exception. Apart from low budget deficits, similar to the values observed in the Czech Republic or Estonia, the strict monetary policy has been a major factor behind the successful process of disinflation. The BOS carried out massive sterilized and non-sterilized interventions in response to large capital inflows. The interventions were needed continuously, causing serious problems for monetary policy. ${ }^{17}$ As, in addition, the BOS was becoming increasingly concerned about problems that might arise when capital enters into a weak banking system, the URR on financial credits was introduced in 1995.

At least since 1996, current account developments in Slovenia were quite different from those in the other accession states. While current account deficits reached values up to 10 percent in the Czech Republic or Estonia, the Slovene current account was almost balanced between 1995 and 1997, and showed a relatively small deficit of 1 percent of GDP in 1998. At the same time, net capital inflows grew continuously from 0.8 percent of GDP in 1994 to almost 7 percent in 1997. Prima facie, the URR seems not to have been successful in containing capital inflows. The steady capital inflow, together with the (unofficial) exchange rate target, caused reserves to grow steadily since 1995. Starting out with reserves covering only 1.5 months of imports in 1993, reserve coverage reached 4.3 months in 1997 which is roughly in line with values observed in the Czech Republic, Estonia, or Hungary.

In 1998, capital inflows witnessed a conspicuous turn-around, and even a minor net outflow of capital was registered. This turn-around was caused by a substantial reduction in FDI and inward portfolio investment, on the one hand, and by lower holdings of foreign assets within the category other investments on the other hand. ${ }^{18}$

\footnotetext{
${ }^{17}$ See BOS $(1997,1998)$.

${ }^{18}$ Within the category „other investments+ trade credits granted by Slovenia increased by 40 per cent and currency and deposit holdings abroad were reduced. Reserve accumulation virtually ceased. See for details BOS (1999b).
} 


\section{Effectiveness of Capital Controls}

The previous section has suggested that the Slovene URR has not affected necessarily the level of overall capital inflows. This section presents more evidence on the effectiveness of Slovene capital controls. We look at the structure of capital flows, the volatility of capital flows and of exchange rates, the degree of market integration, and the degree of autonomy of the monetary authorities.

\section{A. Structure of Capital Flows}

Capital controls are expected not only to affect the magnitude of capital flows but also their structure. In particular, the Slovene capital account regime has been designed to discourage inflows of (short-term) financial credits as well as inflows of portfolio capital. When comparing the structure of gross capital flows in the accession states (Table 2), at least two caveats need to be borne in mind. First, data on financial credits and portfolio investments have not, in particular in the early reform years, been covered separately in the statistics. Second, as Hungary and Poland have rescheduled and repaid substantial amounts of foreign loans in the 1990s, data on their gross inflows are biased.

Nevertheless, the data show that since the introduction of the capital controls, the share of FDI in Slovenia's capital inflows has declined somewhat. It has, overall, been roughly in line with the values observed in the Czech Republic but below those of Estonia. Portfolio investment inflows into Slovenia were higher, in contrast, than in these two countries. The share of inflows of financial credits was lower than in the Czech Republic but similar to that of Estonia. Like in these two countries, the foreign debt to GDP ratio of Slovenia has increased during the transition period (Table 1). In summary, it is thus not evident that the capital controls have had the intended effect of tilting the structure of capital flows towards FDI.

Even if the Slovene capital controls might not have altered the overall structure of capital inflows, they could yet have been successful in changing inflows of financial credits towards longer-term instruments. Whereas for the region as a whole the share of short-term credits in total foreign loans increased quite considerably between 1994 and 1998, the reverse was indeed true for Slovenia (Table 3). At least since the end of 1994, there has been a decidedly different trend than in the rest of the accession states. In mid-1998, short-term credits accounted for only 18.5 percent of the total, which was less than half of the values observed 
Table 2. Structure of Gross Capital Inflows (1992-1998)

\begin{tabular}{|c|c|c|c|c|c|c|c|c|}
\hline & 1992 & 1993 & 1994 & 1995 & 1996 & 1997 & $\phi^{\mathrm{b}}$ & $1998^{\mathrm{a}}$ \\
\hline & \multicolumn{8}{|c|}{ (in \% of gross inflows) } \\
\hline & \multicolumn{8}{|c|}{ Slovenia } \\
\hline Foreign direct investment & 73.5 & 50.7 & 27.7 & 21.8 & 19.1 & 34.6 & 37.9 & 27.3 \\
\hline Portfolio investment & 0.0 & 2.0 & 0.1 & 1.9 & 64.9 & 25.6 & 15.8 & 19.8 \\
\hline \multirow[t]{2}{*}{ Other investment } & 26.8 & 47.1 & 72.2 & 76.3 & 16.0 & 39.8 & 46.4 & 52.9 \\
\hline & \multicolumn{8}{|c|}{ Czech Republic } \\
\hline Foreign direct investment & $\ldots$ & 10.5 & 14.4 & 23.2 & 21.2 & 22.4 & 18.4 & 52.8 \\
\hline Portfolio investment & $\ldots$ & 29.5 & 14.7 & 15.3 & 11.4 & 20.1 & 18.2 & 8.9 \\
\hline \multirow[t]{2}{*}{ Other investment } & $\ldots$ & 59.9 & 70.9 & 61.5 & 67.5 & 22.0 & 56.4 & 38.2 \\
\hline & \multicolumn{8}{|c|}{ Estonia } \\
\hline Foreign direct investment & 61.4 & 41.8 & 63.2 & 50.7 & 23.8 & 18.8 & 43.3 & \\
\hline Portfolio investment & $\ldots$ & $\ldots$ & 2.3 & 2.8 & 31.4 & 30.1 & 16.7 & ... \\
\hline \multirow[t]{2}{*}{ Other investment } & 38.8 & 58.1 & 34.2 & 46.6 & 44.7 & 51.1 & 45.6 & \\
\hline & \multicolumn{8}{|c|}{ Hungary } \\
\hline Foreign direct investment & 178.2 & 44.8 & 39.6 & 78.6 & -390 & 136 & 71.4 & 54.2 \\
\hline Portfolio investment & $\ldots$ & 74.8 & 85.2 & 38.5 & 167 & -60.2 & 37.7 & 52.9 \\
\hline \multirow[t]{2}{*}{ Other investment } & -78.2 & -19.6 & -24.8 & -17.1 & 323 & 23.9 & -20.5 & $\begin{array}{l}-7.1 \\
\end{array}$ \\
\hline & \multicolumn{8}{|c|}{ Poland } \\
\hline Foreign direct investment & 27.9 & 62.4 & 30.9 & 80.6 & $\ldots$ & 61.8 & 40.4 & 75.9 \\
\hline Portfolio investment & & ... & & 21.0 & $\ldots$ & 16.1 & 21.0 & -0.3 \\
\hline Other investment & 72.1 & 37.6 & 130.9 & -6.5 & $\ldots$ & 22.0 & 51.2 & 24.4 \\
\hline
\end{tabular}

Gross capital inflows=Increase in foreign liabilities (excluding foreign currency reserves). a) Data for 1998 were drawn from national sources and are not necessarily consistent with earlier data. For the Czech Republic: January-September. For Poland: January-November. b) average 1991-1997. For the Czech Republic and Estonia: since 1993 and 1992, respectively.

Source: IMF (1999a, 1999b), NBP (1998), national sources, own calculations.

Table 3. Share of Short-Term Credit in Foreign Bank Loans (1992-1998)

\begin{tabular}{|l|c|c|c|c|c|c|c|}
\hline & $1992^{\mathrm{a}}$ & 1993 & 1994 & 1995 & 1996 & 1997 & $1998^{\mathrm{a}}$ \\
\hline Asia & 59.0 & 62.8 & 62.9 & 63.5 & 61.5 & 60.6 & 53.5 \\
\hline Eastern Europe & 27.3 & 37.2 & 35.2 & 39.1 & 44.2 & 43.4 & 44.7 \\
\hline Czech Republic & $\ldots$ & $\ldots$ & 40.4 & 48.6 & 49.3 & 50.0 & 56.0 \\
\hline Estonia & $\ldots$ & $\ldots$ & 37.9 & 33.8 & 45.8 & 47.8 & 44.7 \\
\hline Hungary & 23.8 & 26.9 & 30.7 & 34.6 & 39.2 & 34.2 & 38.9 \\
\hline Poland & 31.4 & 33.1 & 23.2 & 29.6 & 33.2 & 38.1 & 42.6 \\
\hline Slovenia & $\ldots$ & $\ldots$ & 39.8 & 30.9 & 17.8 & 21.2 & 18.5 \\
\hline Latin America & 43.4 & 50.0 & 51.3 & 52.3 & 53.7 & 54.8 & 55.0 \\
\hline Chile & 42.7 & 52.4 & 53.7 & 54.7 & 51.2 & 49.8 & 45.9 \\
\hline
\end{tabular}

Foreign bank loans comprise liabilities vis-à-vis banks in the BIS reporting area only (maturity $<1$ year). a) June.

Source: BIS $(1994,1998)$. 
in the rest of eastern Europe, in Asia, or in Latin America. On this count, the Slovene capital controls have indeed been a success. Drawing inference from this finding with respect to the impact of the URRs on the stability of the Slovene financial sector, however, would be premature since it would require a much more thorough analysis of the performance of financial institutions in the country.

\section{B. Impact on Volatility}

The previous section has shown that, in the case of Slovenia, the URR seems to have lowered the share of short-term credit in foreign bank lending. The question remains whether this has also lowered the volatility of capital flows. From an empirical point of view, one of the main problems in reducing the volatility of capital flows by means of a "tax" on selective flows is that standard classifications provide little evidence about the actual volatility of different capital account items (Claessens et al. 1995). Short-term capital flows are not necessarily the most volatile item in the capital account of the balance of payments, and the volatility of different capital flows varies from country with country. This finding contrasts to the theoretical argument in that controls on short-term capital flows are frequently advocated as a means to reduce the volatility of capital flows and of exchange rates.

When comparing the volatility of capital flows for Slovenia to that of the other accession states, little evidence for the intended impact of the controls can be found (Table 4). Hereby, we measure volatility as the standard deviation of quarterly capital flows for the years 1992-1998. The sample is split into two periods (1992:1-1994:4 and 1995:1-1998:3) to capture the impact of the controls. We consider data for Slovenia, the Czech Republic, and Estonia only because data for Hungary and Poland are distorted by the debt repayment and rescheduling that has taken place during the 1990s. Moreover, portfolio investments are excluded because of missing observations. With the exception of Czech FDI flows and Estonian portfolio investment flows, the hypothesis that the time series under review are normally distributed could not be rejected on the basis of the JarqueBera test. Hence, we could rely on standard $t$ - and $F$-test to tests for the equality of the mean and of the variance of capital flows in the two sub-periods.

As regards the volume of capital flows, inflows of foreign direct investments into all three countries have increased significantly in the second period. For other investments, in contrast, no significant difference between the two sub-sample is found at the conventional levels of significance for the Czech Republic and 
Table 4. Volume and Volatility of Quarterly Capital Flows (1992-1998)

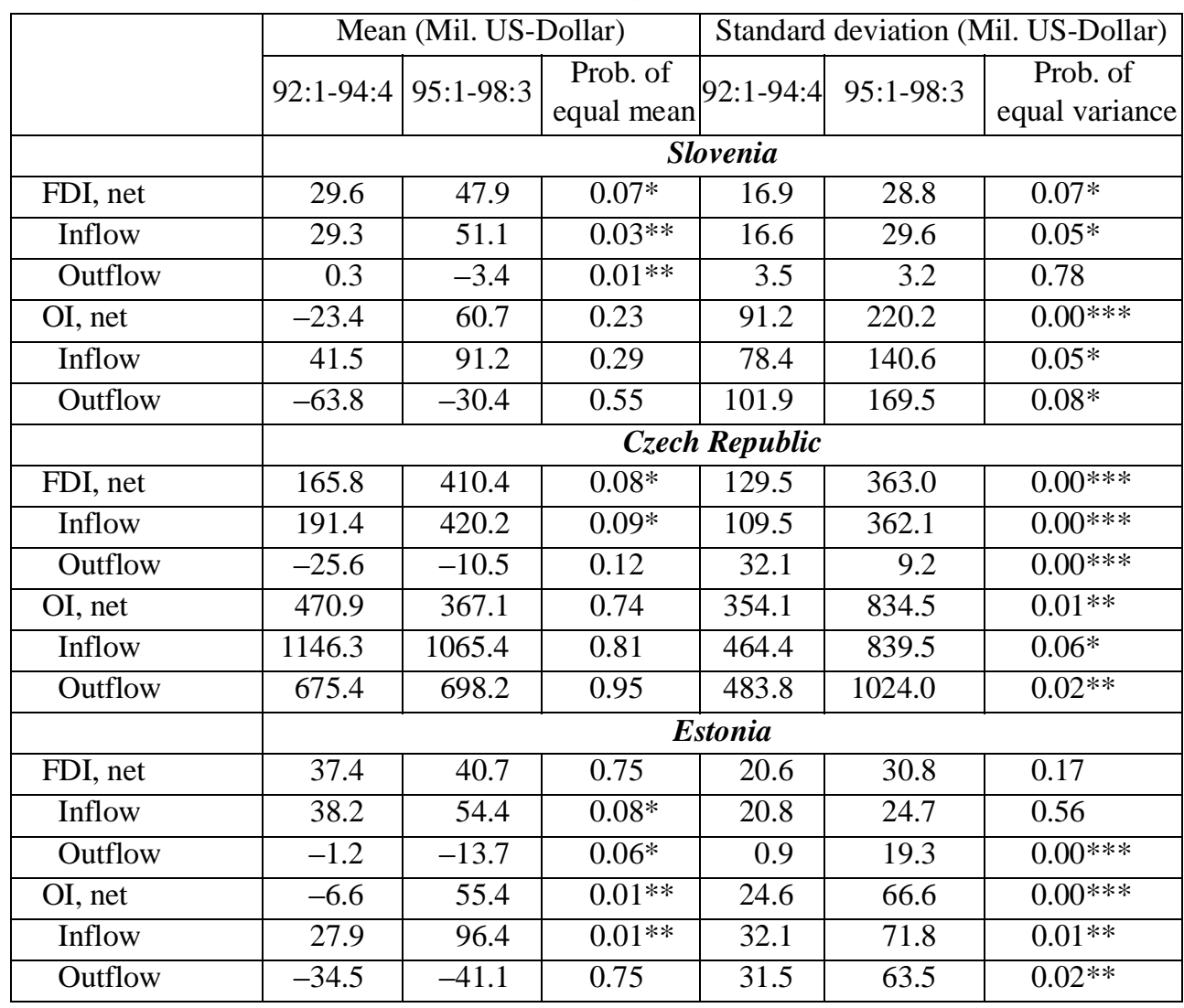

$\mathrm{OI}=$ other investment. Results of $\mathrm{t}-$ and F-tests, respectively, on equality in mean and variance. $*(* *, * * *)=$ significant at the $10(5,1)$-percent level.

Source: IMF (1999b), authors' calculations.

Slovenia. This could be taken as weak evidence for the hypothesis that the Slovene capital controls have not affected the volume of financial credits. Moreover, the capital controls seem not to have been effective in insulating Slovenia from an increase in the volatility of capital flows that has affected all countries and almost all capital account items.

It could be argued that, while there has been a general increase in the volatility of capital flows, the magnitude of this increase might have been smaller in Slovenia than in the other countries. In order to check this hypothesis, the standard deviation of capital flows needs to be normalized by relating it to the mean of the underlying time series. Calculating these coefficients of variations for gross inflows of other investments (i.e. financial credits) shows a decline between the 
two periods from 1.89 to 1.54 for Slovenia. For the Czech Republic, the coefficient of variation increased from 0.41 to 0.79 while for Estonia a decline from 1.15 to 0.74 was observed. Hence, these observations fail to support the hypothesis that the decline in volatility has been greater in relative terms for Slovenia: the coefficient of variation has been higher than in the other two countries throughout, and a decline of a similar magnitude as in Estonia has taken

Table 5. Volatility of Exchange Rates (1992-1997)

\begin{tabular}{|c|c|c|c|c|c|c|}
\hline \multirow{3}{*}{ D-mark } & \multicolumn{3}{|c|}{ Median $^{\mathrm{a}}$} & \multicolumn{3}{|c|}{ Standard deviation $^{b}$} \\
\hline & $92: 1-95: 1$ & 95:2-97:12 & Probability $^{\mathrm{c}}$ & $92: 1-95: 1$ & 95:2-97: & Probability $^{\mathrm{d}}$ \\
\hline & \multicolumn{6}{|c|}{ Slovenia } \\
\hline nominal & 0.11 & 0.04 & $0.00 * * *$ & 0.31 & 0.09 & - \\
\hline real & 0.22 & 0.16 & 0.20 & 0.38 & 0.27 & 0.40 \\
\hline \multicolumn{7}{|l|}{ US-dollar } \\
\hline nominal & 0.34 & 0.23 & 0.20 & 0.62 & 0.29 & $0.09 *$ \\
\hline real & 0.28 & 0.27 & 0.38 & 0.59 & 0.39 & $0.08 *$ \\
\hline D-mark & \multicolumn{6}{|c|}{ Czech Republic } \\
\hline nominal & 0.07 & 0.11 & 0.12 & 0.10 & 0.24 & $0.08 *$ \\
\hline real & 0.09 & 0.12 & 0.16 & 0.10 & 0.23 & 0.12 \\
\hline \multicolumn{7}{|l|}{ US-dollar } \\
\hline nominal & 0.14 & 0.19 & 0.14 & 0.23 & 0.42 & $0.09 *$ \\
\hline real & 0.16 & 0.16 & 0.21 & 0.22 & 0.35 & $0.09 *$ \\
\hline US-dollar & \multicolumn{6}{|c|}{ Estonia } \\
\hline nominal & 0.23 & 0.23 & 0.93 & 0.46 & 0.38 & 0.55 \\
\hline real & 0.34 & 0.21 & $0.01 * *$ & 0.36 & 0.35 & - \\
\hline D-mark & \multicolumn{6}{|c|}{ Hungary } \\
\hline nominal & 0.14 & 0.12 & 0.47 & 0.35 & 0.61 & 0.12 \\
\hline real & 0.19 & 0.10 & $0.03 * *$ & 0.30 & 0.45 & \\
\hline \multicolumn{7}{|l|}{ US-dollar } \\
\hline nominal & 0.16 & 0.23 & 0.59 & 0.36 & 0.29 & $0.03 * *$ \\
\hline real & 0.20 & 0.17 & $0.03 * *$ & 0.35 & 0.24 & - \\
\hline D-mark & \multicolumn{6}{|c|}{ Poland } \\
\hline nominal & 0.24 & 0.15 & 0.15 & 0.54 & 0.21 & 0.87 \\
\hline real & 0.14 & 0.12 & 0.80 & 0.40 & 0.22 & 0.78 \\
\hline \multicolumn{7}{|l|}{ US-dollar } \\
\hline nominal & 0.19 & 0.16 & 0.49 & 0.37 & 0.26 & 0.93 \\
\hline real & 0.18 & 0.13 & 0.10 & 0.40 & 0.22 & - \\
\hline
\end{tabular}

a) Median of absolute changes in exchange rates over previous month at an annual rate. _ b) Standard deviation of change in exchange rates over previous month at an annual rate. _ c) Results of Mann-Whitney $U$-tests on equality in the median. d) Results of Siegel-Tukey test on equality in the variance. _ $*(* *, * * *)=$ significant at the $10(5,1)$-percent level. 
place.

While the volatility of capital flows seems to have increased in the second period, the opposite holds true for the volatility of real and nominal exchange rates. Table 5 uses the monthly changes of exchange rates (at an annual rate) as a measure for exchange rate volatility. In order to look at samples of equal length, we have considered data until the end of 1997 only. In contrast to the capital flow data, the hypothesis that the exchange rate series under review are normally distributed had to be rejected. Consequently, we use the Mann-Whitney $U$-test to test for the equality in the median of the time series in the two sub-periods. Only in those cases where we cannot reject the hypothesis that the median is the same in the two periods, the Siegel-Tukey test on equality of variance is used as well. ${ }^{19}$ Table 5 shows that, for Slovenia, the volatility of nominal exchange rates has declined in the second period. ${ }^{20}$ However, only for the US-dollar did this decline transmit also into a significant decline in the volatility of the real exchange rate.

When interpreting the decline in exchange rate volatility, three caveats should be borne in mind. First, because no explanatory variables have been controlled for, one should be cautious in attributing the decline in volatility to the URR alone. It is, for example, conceivable, that exchange rates in general have become less volatile during the second period. At least for the case of Hungary, a picture similar to that for Slovenia is found. For Estonia and Poland, however, exchange rate volatility has not changed significantly while it has even increased for the Czech Republic. Second, monetary policy has an impact on exchange rate volatility. If the monetary authorities react to changes in capital flows by intervening in the market in order to keep the exchange rate stable, one would observe a stabilization of exchange rates which is independent of the capital control regime. Hence, the fact that the Slovene monetary authorities have implicitly targeted the D-mark exchange rate might have had a dampening effect on the volatility of exchange rates. Third, the results are sensitive to one-time events which are unrelated to the capital control regime. The increase in volatility

\footnotetext{
${ }^{19}$ The Mann-Whitney $U$-test and the Siegel-Tukey test are similar to a Wilcoxon signed-rank test, which is not based on the assumption that the underlying time series are normally distributed. Yet, the SiegelTukey test is computed under the assumption that the median of the time series is the same. For a discussion of the power of these tests and their underlying assumptions see, for instance, Schlittgen (1990: pp. 332) and the EViews User Guide.

${ }^{20} \mathrm{Because}$ of the failure to find evidence for equality of the median for the two periods as well as for a normal distribution of the individual time series, we do not report the results of tests on the equality of the variance. Yet, with the exception of the Siegel-Tukey test, standard tests rejected the hypothesis that the variance in the nominal D-mark rate has been the same in the two periods.
} 
in the Czech Republic, for instance, clearly reflects the impact of the currency crisis of 1997. For Slovenia, exchange rates have been very volatile at the beginning of the period under review. If some of the resulting extreme values are eliminated from the sample, the result that volatility has declined is lost.

\section{Integration of Financial Markets}

In integrated markets, returns on financial assets should be correlated. Arbitrage between markets ensures that return differentials are eliminated, and that changes in fundamentals affect returns at home and abroad. Hence, the co-movement of returns can be taken as evidence for integration. More specifically, the cointegration between interest rates and stock market indices has been used to assess the degree of integration of markets (Artis and Zhang 1998, Bordo et al.

Table 6. Cointegration of Stock Market Indices

\begin{tabular}{|c|c|c|c|c|}
\hline & \multicolumn{2}{|c|}{$\begin{array}{l}\text { Cointegration with } \\
\text { German stock index }\end{array}$} & \multicolumn{2}{|c|}{$\begin{array}{l}\text { Cointegration with } \\
\text { US stock index }\end{array}$} \\
\hline & $\begin{array}{l}\text { National } \\
\text { currency }\end{array}$ & D-mark & $\begin{array}{l}\text { National } \\
\text { currency }\end{array}$ & US-dollar \\
\hline \multicolumn{5}{|l|}{ Explanatory variables } \\
\hline Constant & $\begin{array}{l}1.78^{* * *} \\
(3.46)\end{array}$ & & $\begin{array}{l}1.55^{* * * *} \\
(3.08)\end{array}$ & $\begin{array}{l}0.61^{*} \\
(1.69)\end{array}$ \\
\hline$X_{-1}$ & $\begin{array}{c}-0.40^{* * *} \\
(-4.22)\end{array}$ & $\begin{array}{c}-0.31 * * * \\
(-3.83)\end{array}$ & $\begin{array}{c}-0.37 * * * \\
(-4.10)\end{array}$ & $\begin{array}{r}-0.28^{* * *} \\
(-3.28)\end{array}$ \\
\hline$X_{-1}^{*}$ & $\begin{array}{l}0.19 * * * \\
(3.30)\end{array}$ & $\begin{array}{l}0.15 * * * \\
(3.78)\end{array}$ & $\begin{array}{l}0.19 \text { *** } \\
(3.21)\end{array}$ & $\begin{array}{l}0.01 \\
(0.22)\end{array}$ \\
\hline$\Delta X_{-3}$ & $\begin{array}{l}0.33^{* * *} \\
(2.75)\end{array}$ & $\begin{array}{l}0.29 * * \\
(2.44)\end{array}$ & $\begin{array}{l}0.33^{* * * *} \\
(2.76)\end{array}$ & $\begin{array}{l}0.31 * * \\
(2.52)\end{array}$ \\
\hline Dummy (capital controls) & $\begin{array}{r}-0.08^{* *} \\
(-2.22)\end{array}$ & $\begin{array}{r}-0.09^{* *} \\
(-2.37)\end{array}$ & $\begin{array}{r}-0.11 * * * \\
(-2.56)\end{array}$ & $\begin{array}{l}-0.06 \\
(-1.57)\end{array}$ \\
\hline JB (prob.) & 0.46 & 0.35 & 0.67 & 0.79 \\
\hline LM1 (prob.) & 0.16 & 0.37 & 0.22 & 0.42 \\
\hline LM4 (prob.) & 0.42 & 0.88 & 0.57 & 0.62 \\
\hline White (prob.) & 0.58 & 0.62 & 0.44 & 0.33 \\
\hline$R^{2}$ & 0.23 & 0.22 & 0.23 & 0.16 \\
\hline Period & $94: 5-98: 12$ & $94: 5-98: 12$ & $94: 5-98: 12$ & $94: 5-98: 12$ \\
\hline
\end{tabular}

All variables in logs. _ Dummy=variable capturing capital controls takes the value of zero before February 1995 and 1 afterwards. _ Significance levels for the error correction term were taken from the Bewley-transformed equation. Critical values were taken from Banerjee $e t$ al. $(1992)$ for $\mathrm{T}=50$. $\mathrm{t}$-values appear in parentheses. $* * *(* *, *)=$ significant at $1(5,10)$ percent level.

Sources: Datastream, authors' calculations. 
1998, Chou et al. 1994, Linne 1998). Hence, failure to find cointegration could be interpreted as a lack of integration because of, for instance, the presence of capital controls.

At the same time, it has been argued that the presence of a cointegration relationship implies the rejection of asset pricing models based on serially uncorrelated excess returns. Hence, cointegration would imply inefficiency of markets (Richards 1995). However, as Dwyer and Wallace (1992) show, there is no general equivalence between cointegration and the presence of arbitrage opportunities. ${ }^{21}$ Moreover, a significant long-run cointegration relationship between two variables does imply predictability only if the direction of causality is uniquely determined. Finally, a stable long-run relationship between two variables cannot be taken as evidence for a stability of the short-run relationship, on which arbitrage possibilities would be based.

Table 6 reports the results of testing for cointegration between Slovene and German (US) financial market variables. The following equation has been estimated:

$$
\begin{aligned}
\Delta X_{t}= & c_{t}+\left(\alpha_{0}+1\right)_{t-1}-\beta_{i}\left(\alpha_{0}-1\right) X_{t-1}^{*}-\sum_{i=1}^{n} \alpha_{i} \Delta X_{t-i}-\sum_{i=0}^{m} \gamma_{i} \Delta X_{t-i}^{*}+ \\
& \varepsilon_{t}+\text { dummy }_{t}+t_{t}
\end{aligned}
$$

where $X$ and $X^{*}$ are the Slovene and the foreign financial market variables (money market rates and stock indices), and $t$ denotes a linear time trend. All variables have been seasonally adjusted using an additive technique. Using a general-tospecific method, four lags of the dependent and the independent variable were included in each equation originally, and insignificant lags were excluded successively. For stock indices, indices in local currency and in the respective foreign currency have been used. Data are for the Slovene stock index (SBI) as well as Datastream total market indices (price indices) for the German and US stock market. Although the URR has not directly affected access to the Slovene stock market, it could yet be argued that indirectly market access has been influenced by the presence of capital account restrictions. Also, portfolio investment flows have been regulated directly, and, since February 1997, portfolio investment can officially be effected only through custody accounts at licensed

\footnotetext{
${ }^{21}$ For a similar argument see Engel (1996).
} 
banks. For the German stock index in domestic currency terms, the constant term was insignificant and was thus dropped without changing the remaining results.

For stock indices, statistically significant cointegration relationships are found. ${ }^{22}$ An exception is the equation involving the Slovene and the US stock index, both measured in US-dollar-terms. The long-run elasticity with respect to changes in the foreign stock index is positive and approximately equals 0.5. About one fourth of the variation in the Slovene index is explained. A capital control dummy, which is set equal to zero prior to the first introduction of the URR on financial credits in February 1995 and equal to one subsequently, enters with a significantly negative sign in all equations. This could be interpreted as evidence for the hypothesis that the capital controls have lowered the Slovene stock index. ${ }^{23}$ At the same time, the controls have not been effective in iusulating the Slovene stock market from global trends, as evidenced by the presence of cointegration relationships.

As regards interest rates, Buch and Döpke (1999) found evidence for a positive relationship between Slovene and German short-term interest rates. However, no such relationship was found for US interest rates. When entering the capital control dummy, also the evidence for a cointegration relationship between Slovene and German interest rates weakens considerably. Also, key assumptions underlying the validity of the error-correction estimates (normal distribution of the residuals, non-stationarity of the domestic interest rate series) are not met. In summary then, we fail to find a statistically significant and robust impact of the URR on the cointegration between Slovene and foreign interest rates.

\section{Autonomy of Monetary Policy}

Finally, URRs can have an impact on the autonomy of the monetary authorities by affecting the effectiveness of sterilization policies. Such evidence, in turn, can be obtained through estimates of offset coefficients which measure the fraction of domestic credit expansion reversed by central bank foreign reserve losses (Obstfeld 1982: 46). Offset coefficients can be estimated from reduced form

\footnotetext{
${ }^{22}$ All three stock indices are I(1). The non-stationarity of the series under review has been tested by means of an Augmented Dickey-Fuller test. To save space, results are not reported but are available from the authors upon request.

${ }^{23}$ In a discussion, it has been pointed out by David Moore that the period during which the URR has been in effect has also been the period when less profitable firms have been privatized. This might have led to a downward shift in the stock index unrelated to the URR.
} 
equations which relate changes in central bank net foreign assets (NFA) to changes in net domestic assets $(N D A)$ and other explanatory variables $(X)$ such as income and the expected return on foreign assets (Schadler et al. 1993; Frankel and Okungwu 1995): ${ }^{24}$

$$
\Delta N F A_{t}=\alpha \Delta N D A_{t}+\beta X_{t}+\varepsilon_{t}
$$

If the offset coefficient $\alpha$ is equal to -1 , offset is complete, i.e., an increase in domestic credit does not increase money supply. It automatically leaks through the capital account, and foreign exchange reserves are reduced. Under flexible exchange rates, the effect would of course be on the exchange rate rather than the capital account-the offset coefficient would be zero.

Conceptually, there are two problems with the estimation of reduced-form equations. First, net domestic assets of the central bank are not exogenous if the central bank follows a sterilization policy. OLS estimates of $\alpha$ are therefore biased towards -1 (Roubini 1988). Second, equation (1) can be derived from a structural model which takes the reaction function of the central bank into account (Cumby and Obstfeld 1981, Roubini 1988). Yet, there is a trade-off between the accuracy gained by estimating components of the offset coefficients separately, on the one hand, and the possible errors through mis-specification of the structural equations, on the other hand. Hence, we have confined our analysis to the estimation of reduced-form offset equations in which we test for the exogeneity of domestic assets. We have followed Schadler et al. (1993) in approximating the return on foreign financial assets by foreign interest rate only.

When estimating equation (2) in the form of an error-correction model, ${ }^{25}$ we have found some weak evidence for a cointegration relationship between the monetary authorities net foreign assets, on the one hand, and their net foreign assets, real GDP, and German interest rates, on the other hand. Moreover, the estimated offset coefficient was statistically insignificant from 1 . This could be taken as evidence for a high degree of capital mobility and a low degree of autonomy of the BOS. The capital control dummy entered with a positive sign, implying that net foreign assets have increased after the imposition of the URR. Yet, these results have not been robust against changes in the specification of the equation, and should thus be interpreted with extreme caution.

\footnotetext{
${ }^{24} \mathrm{~A}$ related approach is to measure the offset coefficient by estimating the capital account response to a change in domestic credit (Obstfeld, 1982).

${ }^{25}$ The non-stationarity of the underlying time series has been tested with an Augmented Dickey-Fuller test. The series under review are all non-stationary at the 1 percent critical value.
} 


\section{Summary}

Being a small economy on the fringe of the center of Europe, Slovenia oftentimes slips the attention of outside observers. Yet, not least because of the relative unique strategy the country has followed in opening up for foreign capital, greater attention is warranted. Similar to Chile in the 1990s, Slovenia has introduced an URR on financial credits in 1995, and lowered the reserve rate to zero recently. Hence, the case of Slovenia provides potentially interesting evidence with respect to the effectiveness and the effects of Tobin-type taxes on (short-term) capital flows. Because of the comparatively weak underlying database, not all measures presented in this paper point into the same direction and not all of the results are clear-cut. Yet, a few conclusions can be drawn.

First, the URR seems not to have been overly effective in reducing overall inflows of foreign capital. Rather, net inflows of capital relative to GDP have increased continuously between 1993 and 1997. In an effort to prevent an appreciation of the tolar, the BOS has sterilized these capital inflows, and reserves have been accumulated. The gain in monetary autonomy has therefore been limited.

Second, while the overall structure of capital inflows has not differed decidedly from other transition economies such as the Czech Republic or Estonia, Slovenia has raised much less short-term bank credit from abroad. This could be taken as a direct effect of the high costs that the reserve requirement has imposed on shortterm financial credits.

Third, concerning the volatility of capital flows and exchange rates, two opposing results are found. While the volatility of exchange rates has tended to decline after the controls had been imposed, this has not been the case for the volatility of capital flows. This presumably reflects the fact that the BOS has intervened into the foreign exchange market to smoothen out the impact of volatile capital flows on the exchange rate. ${ }^{26}$ Although one should be cautious in attributing changes in volatility to the imposition of the capital controls alone, the results indicate that the controls have been unsuccessful in shielding the Slovene economy from an increase in the volatility of financial flows that has hit the region in the recent past. The fact that stock returns in Slovenia were found to be cointegrated with stock returns in Germany or in the US also shows the close links

\footnotetext{
${ }^{26} \mathrm{~A}$ similar effect is found for Chile. See Laurens and Cardoso (1998).
} 
between financial markets that exist. Moreover, it is interesting to stress that despite the decline in the share of short-term credit, the volatility of capital flows has not decreased.

Overall, our analysis supports the results of earlier studies which found relatively limited and short-lived effects of capital controls. Although we have not attempted to measure the overall welfare implications of the Slovene capital controls, this would lead us to conclude that the recent de facto abolition of the URR has not harmed the Slovene economy to a significant degree. Rather, dropping the controls entirely might have the beneficial effect of signaling (foreign) investors the willingness to pursue reforms in the future and to fully commit to the requirements of EU and OECD membership.

(June 1999 First Version, February 2000 Revised Version)

\section{References}

Artis, M.J. and W. Zhang (1998), "The Linkages of Interest Rates Within the EMS," Weltwirtschaftliches Archiv 134(1), 117-132.

Bank for International Settlements (1994, 1998), Maturity, Sectoral and Nationality

Distribution of International Bank Lending, Basel.

Bank of Slovenia (1997), Annual Report 1996, Ljubljana. (1998), Annual Report 1997, Ljubljana.

(1999a), Foreign Exchange Regime in Slovenia, http://www.bsi.si/html/eng/

laws_regulations/ foreign_exchange.html, Website as of March 19, 1999.

(1999b), Monthly Bulletin, Various Issues, Ljubljana.

Bartolini, L., and A. Drazen (1997), "Capital-Account Liberalization as a Signal," American Economic Review 87, 138154.

Bordo, M.D., B. Eichengreen, and J. Kim (1998), "Was There Really an Earlier Period of International Financial Integration Comparable to Today?" National Bureau of Economic Research (NBER), Working Paper 6738, Cambridge MA.

Buch, C.M., and J. Döpke (1999), "Real and Financial Integration in Europe-Evidence for the Accession States and for the Pre-Ins," Kiel Institute of World Economics, Working Paper 917, Kiel.

Buch, C.M., R.P. Heinrich, and C. Pierdzioch (1998), "Taxing Short-Term Capital Flows: An Option for Transition Economies?," Kiel Institute of World Economics, Discussion Paper 321, Kiel. (1999), Foreign Capital and the Transformation Process Risks and Benefits of Free Capital Flows, Kiel Institute of World Economics, Kiel Study 295.

Chou, R.Y., V.K. Ng, and L.K. Pi (1994), "Cointegration of International Stock Market Indices. International Monetary Fund. Working Paper 94/94, Washington, DC. 
Claessens, S., M.P. Dooley, and A. Warner (1995), "Portfolio Capital Flows: Hot or Cold?," Harvard Institute for International Development, Development Discussion Paper 501, Cambridge, MA.

Commerzbank (1999), “Capital Markets. Eastern Europe," Macroeconomic Indicators, http://www.ccme.cz/pages/macroind.html, Website as of April 19, 1999, Prague.

Cordoso, E., and I. Goldfajn (1998), "Capital Flows to Brazil The Endogeneity of Capital Controls," IMF Staff Papers 1(45), 161-198.

Cumby, R.E., and M. Obstfeld (1981), "Capital Mobility and the Scope for Sterilization: Mexico in the 1970s,” International Finance Discussion Paper 187.

Czech National Bank (CNB) (1995), Devisengesetz, Nr. 219/1995 der Gesetzessammlung vom 26, September, Prague.

(1998), Annual Report 1997, Prague.

Dooley, M.P. (1996), "A Survey on Controls over International Capital Transactions," IMF Staff Paper 43(4), 639-687.

Dooley, M.P., and M. Chinn (1995), "Financial Repression and Capital Mobility: Why Capital Flows and Covered Interest Differentials Fail to Measure Captial Market Integration," National Bureau of Economic Research (NBER), Working Paper 5347, Cambridge, MA.

Dooley, M.P., D.J. Mathieson, and L. Rojas-Suarez (1997), "Capital Mobility and Exchange Rate Market Interventions in Developing Countries," National Bureau of Economic Research (NBER), Working Paper 6247, Cambridge, MA.

Edwards, S. (1998), "Capital Flows, Real Exchange Rates, and Capital Controls," Some Latin American Experiences, National Bureau of Economic Research (NBER), Working Paper 6800, Cambridge, MA.

Edwards, S., and M.S. Khan (1985), "Interest Determination in Developing Countries, International Monetary Fund," IMF Staff Paper 32(3), 377-403.

Eichengreen, B. (1999), “Toward a New International Financial Architecture A Practical Post-Asia Agenda," Institute for International Economics, Washington, DC.

Eichengreen B., M. Mussa, G. DellAriccia, E. Detragiache, G.M. Milesi-Ferretti, and A. Tweedie (1998), "Capital Account Liberalization. Theoretical and Practical Aspects, International Monetary Fund," Occasional Paper 172, Washington, DC.

Engel, C. (1996), "A Note on Cointegration and International Capital Market Efficiency," Journal of International Money and Finance 15(4), 657-660.

Eesti Pank (1999), Statistical Datasheets. March. Tallinn. (1998), Capital Adequacy Report Manual of Credit Institutions and the Reporting

Procedures on the Solo and on the Consolidated Basis, June 30, Tallinn.

European Commission (1999), Regular Report from the Commission on Progress Towards Accession, October 19, 1999. Brussels.

Fischer S., R.N. Cooper, R. Dornbusch, P.M. Garber, C. Massad Abud, J.J. Polak, D. Rodrik, and S.S. Tarapore (1998), "Should the IMF Pursue Capital-Account Convertibility?," Essays in International Finance 208, May, International Finance Section, Department of Economics. Princeton University, NJ. 
Frankel, J.A., and C. Okungwu (1995), "Liberalized Portfolio Capital Inflows in Emerging Markets: Sterilization, Expectations, and the Incompleteness of Interest Rate Convergence," National Bureau of Economic Research (NBER), Working Paper 5156, Cambridge, MA.

Guitian, M. (1999), "Economic Policy Implications of Global Financial Flows," International Monetary Fund, Finance and Development 36: 1, Washington, DC.

Haque, N., and P. Montiel (1991), "Capital Mobility in Developing Countries: Some Empirical Tests," World Development 19 (October), 91-98.

International Monetary Fund (IMF) (1998a), Exchange Arrangements and Exchange Restrictions. Annual Report, Washington, DC.

(1998b), Republic of Slovenia Recent Economic Developments. Washington, DC. (1999a), Balance of Payments Statistics Yearbook, Washington, DC. (1999b), International Financial Statistics on CD-Rom, March, Washington, DC.

Johnston, B.R., and N.T. Tamirisa (1998), "Why Do Countries Use Capital Controls?," International Monetary Fund, IMF Working Paper 181, Washington, DC.

Johnston, B.R., and C. Ryan (1994), “The Impact of Controls on Capital Movements on the Private Capital Accounts of Countries Balance of Payments Empirical Estimates and Policy Implications.” International Monetary Fund, IMF Working Paper 78, Washington, DC.

Krugman, P.R. (1998), "What Happened to Asia?, "http://web.mit.edu/krugman/ 9.1.1998.

Kuori, P.J.K, and M.G. Porter (1974), "International Capital Flows and Portfolio Equilibrium," Journal of Political Economy, 443-467.

Laurens, B., and J. Cardoso (1998), "Managing Capital Flows, Lessons from the Experience of Chile," International Monetary Fund, IMF Working Paper 168, Washington, DC.

Lavrac, V., and P. Stanovnik (1997), "Monetary Policy under a Flexible Exchange Rate in Slovenia," In: P. Gáspár (Ed.). Macroeconomic Issues and Recovery in Transition Economies, Akadémiai Kiadó. Budapest, 149-167.

Lee, J.Y. (1996), "Implications of a Surge in Capital Inflows; Available Tools and Consequences for the Conduct of Monetary Policy," International Monetary Fund, IMF Working Paper 52, Washington, DC.

Linne, T. (1998), "The Integration of the Central and East European Equity Markets into the International Capital Markets," Forschungsreihe, Institute for Economic Research Halle, December.

McKinnon, R.I., and H. Pill (1995), "Credible Liberalizations \& International Capital Flows: The Over-Borrowing Syndrome," Center for Economic Policy Research, Policy Paper 437, Stanford University, Stanford, CA.

Moore, D., and P. Zajc (1999), "Implementing Bank Privatisation in Slovenia," Kiel Institute of World Economics, Kiel Advanced Studies Working Papers 337, Kiel.

Nadal-De Simone, F., and P. Sorsa (1999), "A Review of Capital Restrictions in Chile in the 1990s," IMF Working Paper WP/99/52, Washington, DC. 
National Bank of Poland (NBP) (1998), "Information Bulletin, No. 1-11, Warsaw.

Newey, W., and K. West (1987), "A Simple Positive Semi Definite, Heteroscedasticity and Autocorrelation Consistent Covariance Matrix," Econometrica 55, 703-708.

Obstfeld, M. (1982), "Can we Sterilize? Theory and Evidence," American Economic Review 72(2), 45-50.

Obstfeld, M. (1993), "International Capital Mobility in the 1990s," National Bureau of Economic Research (NBER), Working Paper 4534, Cambrigde, MA.

Organization of Economic Co-operation and Development (OECD) (1997), Slovenia Economic Surveys 1996-1997, Paris.

Quirk, P.J., and O. Evans (1995), "Capital Account Convertibility. Review of Experiences and Implications for IMF Policies," International Monetary Fund, Occasional Paper 131.

Richards, A.J. (1995), "Comovements in National Stock Market Returns: Evidence of Predictability," but not Cointegration, Journal of Monetary Economics 36, 631654.

Riedel, J. (1997), "Capital Market Integration in Developing Asia," World Development, 1-19. Roubini, N. (1988), "Offset and Sterilization under Fixed Exchange Rates with an Optimizing Central Bank.” National Bureau of Economic Research (NBER), Working Paper 2777, Cambridge, MA. (1999), "Website on Asian and Global Financial Crisis," http://www.stern. nyu.edu/ $\sim$ nroubini/asia/AsiaHomepage.html.

Sarno, L., and M.P. Taylor (1999), "Hot Money, Accounting Lables and the Permance of Capital Flows to Developing Countries: An Empirical Investigation," Journal of Development Economics 59, 337-364.

Schadler, S., M. Carkovic, A. Bennett, and R. Khan (1993), "Recent Experiences with Surges in Capital Inflows," International Monetary Fund, Occasional Paper 108, Washington, DC.

Schlittgen, R. (1990), Einführung in the Statistik Analyse und Modellierung von Daten, 2nd edition, R. Oldenbourg Verlag (München and Wien).

Tobin, J. (1978), “A Proposal for International Monetary Reform,” Eastern Economic Journal 4(3/4), 153-159.

Valdés-Prieto, S., and M. Soto (1998), "The Effectiveness of Capital Controls: Theory and Evidence from Chile," Empirica 25, 133-164. 